\title{
Presidential Campaigns Made by Candidates' Spouses in 2008 and 2016: a Comparative Study
}

\begin{abstract}
Each presidential candidate in modern political campaigns in the United States needs to have a spouse behind their back. The involvement of recent candidates' spouses like Michelle Obama and Melania Trump provides researchers with a fresh picture of how a future first lady should or should not behave during campaigning. The interesting matter would be in this article to compare those two candidates' spouses. Their activities and behavior during their first presidential campaigns in 2008 and 2016 will show the differences in Democratic and Republican form of campaigning. The study aims to observe certain regularity in the treatment of spouses during presidential campaigns in the United States. Its goal is to answer what kind of future presidential spousal behavior during campaign is more desirable in order to achieve as many votes as possible. The paper is based on qualitative analysis of already existing data compiled during both elections, as well as critical reading of the literature of the subject. To elaborate, the author will mostly compare the political positions of those two future first ladies - Michelle Obama and Melania Trump - during the mentioned campaigning periods, and also by statistics relating to their presence in media and public appearances.
\end{abstract}

Key words: presidential campaign, presidential spouses, Democratic Party, Republican Party, candidates' spouses

\section{Introduction}

$\Delta$ ssuming that none of American Presidents may exist without a spouse behind their back, this article focuses on the remarkable role that future first ladies have played in leading their husbands to presidential victory in the elections of 2008 and 2016. The aim of this paper is to compare the first presidential campaigns of both Michelle Obama and Melania Trump, as well as analyzing their behavior and activities they undertook in order to achieve as many votes as they could for their husbands. As the first campaign is undoubtedly more difficult than the reelection campaign in American elections, the author has chosen to make a comparative studies of the 2008 and 2016 campaigns and the main field of interest is that the dissertation will compare the activities of Michelle Obama during the 2008 elections and the activities of Melania Trump during the 2016 elections. The main goal of the article is to first show how activities of the future first ladies during the campaign influences the factor of favorability for each presidential candidate and his spouse. The second goal is to is to present how those activities may link with votes - particularly from different groups of women - educated, immigrant, working mothers, African-American etc. The author mainly focuses on the most relevant period between the official party nomination of each candidate - Barack Obama and Donald Trump - until election day. In order to justify this choice, it is argued, that this is 
a comparable period of time. Each of candidates' spouses had the same short period of time to present themselves in front of thee wider public and to convince them to vote for their husbands. They have started in July or August and finished in November - and in this certain time, they have only one candidate to compete with. This is therefore a comparable period of time which helps to show how much each of the mentioned candidates' spouses have done and how they helped to change the results of elections.

These ladies have been taken under consideration for at least two reasons. First, in order to emphasize the differences between the future first lady's role in campaigning by the Democrats and the Republicans. The author would like to prove if this role is the same in both camps or is there any advantage of "behind-the-scene" or "front-row place" for candidates' spouses during the campaign. The first type would rather be focused mainly on the candidate - showing him and his political ideas in public and pushing family relations, particularly his spouse, to the background. While the second type allows for the candidate's spouse to actively participate in the campaigning process independently but also along with the candidate himself.

The comparison of both Michelle Obama and Melania Trump in the media will also show the differences in the treatment that both ladies received during campaigning in all sorts of social and traditional media (Scharrer, Bissell, 2000). The final aim of the author is to demonstrate whether there any better strategy for future presidential candidates than to stand by their spouses during the campaign. The paper therefore tries to ascertain whether one of those above-mentioned types of candidates' spouse's participation in campaigning is better than the other and which one brings better results in convincing voters to vote for their partner.

The paper is based on the qualitative analysis of the already existing data compiled during both elections, as well as critical reading of the literature of the subject. To elaborate the author will mostly compare the political positions of those two future first ladies during the aforementioned campaigning periods, but also by the statistics relating to their presence in media and their public appearances. It should help place Michelle Obama and Melania Trump as one of two types - either "behind-the-scenes" or in a "front-row place" during the campaign. The article will than analyze which from those types is more effective in achieving votes for presidential candidates.

\section{When it begins}

The real race for the presidential position starts soon after the primaries, especially during the first campaigns. This level of competition is extremely hard to survive for novice candidates. Both Barack Obama and Donald Trump have had a wide range of opponents in their campaigns before gaining the official nomination from their party. As Barack Obama was forced to face such personalities as Hillary Clinton, Donald Trump was forced to fight against such "strong players" as Ted Cruz or Marco Rubio. Those mentioned above have a lot in common during the campaigning process after winning the primaries. Not only this preselection process was tough to survive - both of candidates had more to overcome than their opponents - Obama had to show during the campaign that the race card is no longer an issue in American society, but on the other hand 
Trump presented that being politically correct in our contemporary world is no longer a desired attribute for presidential candidates. In both cases, they were accompanied by their spouses, and proved that the performance of presidential spouses on the campaign trail had the potential to influence the success or failure of their spouses' campaigns (MacManus, Quecan, 2008, pp. 337-348).

On the $27^{\text {th }}$ of August 2008 at the Democratic National Convention, the Democratic Party formally nominated Barack Obama to run for the office of the President of the United States of America. The Convention took place more than a month after Hillary Clinton formally ended her candidacy and endorsed Obama, making him the party's nominee. After officially receiving the endorsement, there is a time for traditional speeches from both the candidate and their spouse. Michelle Obama had to present herself without mistakes, as after her speech in Milwaukee on February 2008, she had learnt a vital lesson'. Her speech during the National Convention was memorable, and the impact lasted for the rest of the campaign. Certainly, Mrs. Obama carefully chose her words and rehearsed each and every phrase of the speech (Obama, 2018, pp. 125-126). For the first time she filled her address with personal details, while she expressed her desire for a fairer and more tolerant society (Obama, 2008). She emphasized Barack Obama as a husband and father who lived his life imbued with American values. She portrayed Obama as having come from humble beginnings and as a patriot who shared American values. He had worked as a community organizer in Chicago alongside with people who believed, "like you and I believe, that America should be a place where you can make it if you try" - as she mentioned during her speech. Nevertheless, Michelle Obama strongly focused on her personal life, particularly her early life in Chicago's South Side and presented herself as a working mother of two children. She asked her brother to introduce her and afterwards strongly indicated her connection to her family and her all-American family values. She not only focused on Obama as expected, but also put herself together with average American voters with who she shared common everyday problems. ${ }^{2}$ It should not be forgotten that for most of the time she was accompanied by her daughters. Of course, after this remarkable speech in Denver, Michelle Obama continued her support for her husband in the campaign by presenting herself in all the media outlets.

During the respective period of time in 2016 Melania Trump was not less active. After the primaries in 2016, she stood by her spouse at the Republican National Convention in Cleveland, Ohio. Mrs. Trump delivered a very calm speech in a strong Eastern European accent that appeared to charm most delegates, who applauded her strongly. It was a big breakthrough as at the time she could have become America's first foreignborn First Lady since Louisa Adams in the 19th century, and furthermore, the first one born and raised in a Communist nation. During her speech, she focused on her childhood in Slovenia and all the experience she gained by growing up in certain conditions, but

${ }^{1}$ During her speech in Milwaukee, Wi, Michelle Obama said "...for the first time in my adult life I am proud of my country because it feels like hope is finally making a comeback." what was treated as an assault of the country and hypocrite - shortly used by Republicans in campaign (Oinounou, Kapp, 2015).

2 "And as I tuck that little girl and her little sister into bed at night, I think about how one day, they'll have families of their own. And one day, they - and your sons and daughters - will tell their own children about what we did together in this election" (Obama, 2008). 
then she described moving to New York and becoming a US citizen a decade ago as "the greatest privilege on planet Earth" (Elder, Frederick, Burrell, 2018, pp. 112-117). She expressed her support and willingness to participate in her husband's race for the presidential victory (Kelley, 2016). As Michelle Obama did, she emphasized the importance of values that she and her husband believed in. She absolutely strengthened emotions relating to shared common values such as family, hard working or respect for all people. Trump's spouse has decided to share with her listeners about the expectations she shares with her husband's victory, such as a bright future for children's upbringing in America. She encourages voters with the words "if you want someone to fight for you and your country, I can assure you he [Donald Trump] is the guy. He will never, ever give up and most importantly he will never, ever let you down. Donald is and always has been an amazing leader. Now he will go to work for you." The future first lady intensified the sense of unity in the nation after Trump's victory by saying "His success indicates inclusion rather than division. Donald intends to represent all the people, not just some of the people." Nevertheless, she gave little detail about her plans for the role apart from saying the cause of children and women is close to her heart.

After both speeches, the media responded extremely quickly. It was one of the first speeches given by an official candidates' spouse. Following Michelle Obama's speech, the media gave a lot of attention to her "personal and sentimental account of life with her husband" (MacAskill, 2008). She also was presented in the media as a person who is trying to close the distance between herself and many Americans and who is at least trying to overcome the impression of being ashamed of her country before, as she indicated in the previously mentioned Milwaukee speech (Kaufman, Langley, 2008). Her attempts to show her husband's personal side met with wide approval (Michelle Obama shows her husband's personal side, 2008) In comparison, the media echo chamber after Melania Trump's speech mostly focused on plagiarism that she and her team committed. In the left-wing media, nearly none of them spoke about the content of Melania Trump's speech. They instead focused on the comparison between her speech with Michelle Obama's speech (Lizza, 2016; Smith, 2016). Although there were also several right - wing journalists such as Erick Erickson or Brit Hume - both from Fox News who acknowledged that the speech was plagiarized. There were a very small group of journalists who tried to defend this act of plagiarism, for example, a Fox co-host called Brian Kilmeade claimed the plagiarism was acceptable because the speech actually applies to her life or Jeanine Pirro (also from Fox) who strongly stood by the fact that "nobody owns the words from Michelle" (Mast, 2019). As the media noticed. Melania Trump made it clear from this speech that her first priority was being a mother and politics was Donald's job, not hers (Ioffe, 2016). The speech made by Trump's wife was supposed to be one of the brightest points of the whole campaign. Expectations were high, particularly as she had performed a very low-profile role during the primaries campaign, and that speech had been seen as a chance to learn more about her, but instead eventually brought a whole range of plagiarism accusations (Elder, Frederick, Burrell, 2018, pp. 112-119).

The interesting issue on the matter of convention speeches was researched by a poll made by The Economist and YouGov (Table 1) where a group of 1300 respondents chosen from the general population answered the question: How much does it bother you that parts of Melania Trump's speech were taken directly from Michelle Obama's speech in $2008 ?$ 
茂
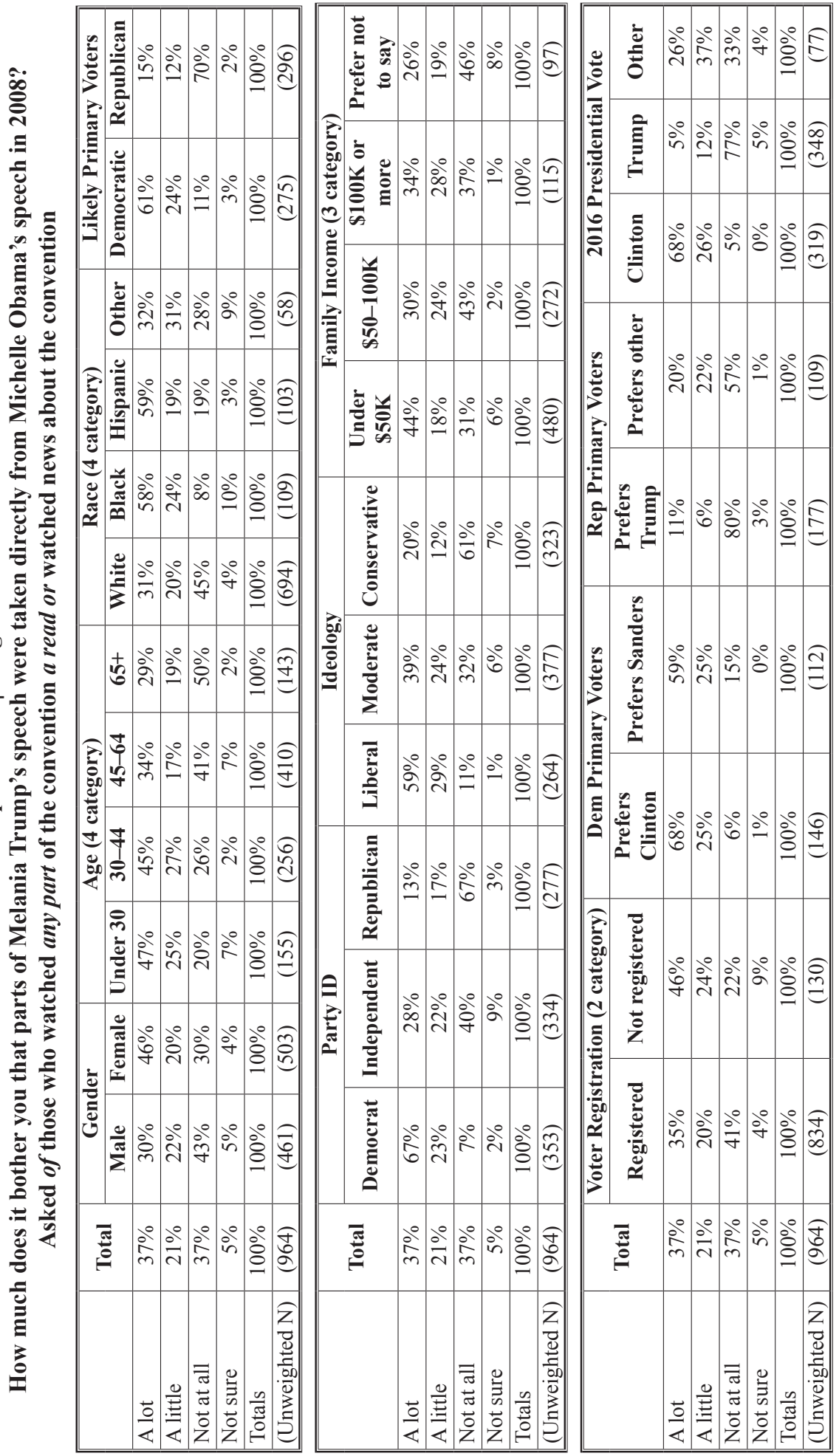

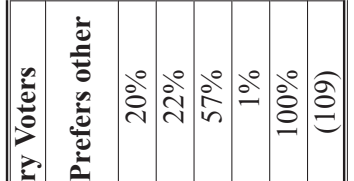
(1)

言离离

\section{章}

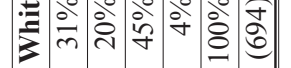

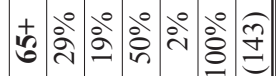

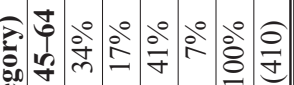

$+$

I.

ले

.

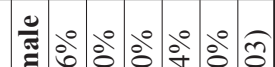

त)

至

跑

$\varangle<$ 乙二に

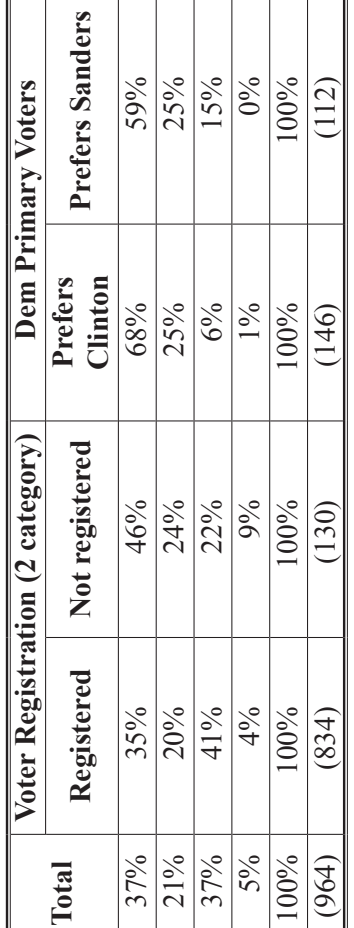

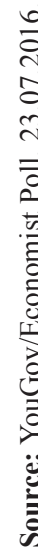


Responses are quite clear in that among $74 \%$ of Americans who watched or heard Trump's Speech - almost $90 \%$ of Democrats agreed that this plagiarism bothered them a lot or a little. While apparently nearly $67 \%$ of Republicans were not bothered. Those opinions are clearly consistent with negative partisanship theory that refers to the tendency of some voters - the Democrats in the mentioned case - to form their political opinions primarily in opposition to political parties they dislike (Bankert, 2020). Furthermore, measuring the rating of favorability for Melania Trump at that time placed her with result of $28 \%$ of favorability (Saad, 2016). Even though Republicans had overwhelmingly positive opinions about Melania's Cleveland speech, it was not reflected in her favorability rating. Although partisanship was not the only interesting factor in that case. What was more interesting was the factor of gender - and how plagiarism influenced opinions about Melania Trump among American women. She was seen worse in women's eyes than in men's as it is indicated in Table 1. Her plagiarism bothered $46 \%$ of women, comparing to only $30 \%$ of men. This result is opposite to favorability ratings in that case. As nearly $45 \%$ of women had a favorable opinion about Melania Trump after her speech (Saad, 2016). It clearly shows that this "plagiarism" has not influenced positive opinions towards Trump's wife among women. Although this incident of plagiarism was used by Clinton's staff at this 2016 campaign as a method of questioning Trump's legitimacy of presidential abilities (Haberman, Barbaro, 2016). Furthermore, in the era of less political polarization, the opinion of Democrats was not as strong as their disapproval in the case of Melania's speech (Gold, 2014).

\section{Campaigning until November}

The path of campaigning activities after the formal nominations of both candidates - Obama and Trump - went strongly in two different directions. Michelle Obama reached unquestionable success after presented herself as vulnerable, while standing in the second row as a mother-in-chief who is strongly supportive of her husband while feeling comfortable when talking about her past and values. On the other hand, Trump's staff were trying to hide Melania during further campaigning.

After August $24^{\text {th }} 2008$ and the Democratic National Convention, ratings for Michelle Obama rose considerably - she became one of the most favored future first lady of all the time (the research of favorability has been made since 1988). All of Obama's advisers decided at the same time that his wife's appearance alone may be a way of gaining female and minority votes (Wright, 2016, pp. 57-59). Contrary to the mentioned negative partisanship theory regarding the Obamas as being the first Black Americans couple in White House, it was not surprising to see that partisanship, ideology or even age made no difference among African Americans and their feelings towards Michelle Obama than other Americans (Brown, 2014, pp. 198-200). As her warm reception after Democratic National Convention had to be used in a proper way for campaigning reasons, she started to appear on many magazine covers. In the period from $24^{\text {th }}$ August until the election day on $4^{\text {th }}$ November 2008 she was placed on nine American magazine covers. She appeared there alone in the position of a strong woman, but on four covers she was accompanied by her husband and daughters. Almost all the covers were on female, entertainment and 
gossip magazines such as "People" (August 2008, November 2008), "Radar" (August 2008) or "Essence" (September 2008), "Marie-Claire" (October 2008). She rarely chose to appear on typically socio-political magazines - and during the mentioned period - she did just once on the cover of "Newsweek," but she has also appeared on the cover of "EBONY" (August 2008) which is issued in Chicago and its target audience is the African-American community. Surprisingly she was not interviewed a lot in this period of time. She gave some interviews during the campaign before primaries, such as her interview on "Larry King Live" in February 2008 or her appearance in "Good Morning America". She was also trying to improve her image by appearing next to Whoopi Goldberg as a co-host on "The View" during the summer 2008, nevertheless she was not interviewed by any magazines after her Convention speech up until the $4^{\text {th }}$ of November. However, it was not an unproductive time for Michelle Obama.

Another major step in Obama's campaign that included his spouse were three debates between Barack Obama and John McCain. The first presidential debate was held on Friday, September 26 at the University of Mississippi, the second presidential debate was held on October 7 at Belmont University in Nashville, while the third one was held on October 15 at Hofstra University in Hempstead. At all of them, Barack was accompanied by Michelle. What was significant was that at first one, she and Barack were captured on a photo where they are hugging each other after the debate as an act of congratulation and pride, but also giving each other reciprocal support as well. After the second debate, the media focused mostly on the picture where Mrs. Obama showed her husband an encouraging sign of a clenched fist. She actually actively participated in this debate, shaking hands and sending gratitude for those watching the debate along with her husband. What was visible in this section of the Belmont debate was that Barack and Michelle were completely independent and separate in the "small talks" that they gave to debate viewers while Obama's opponent's wife (Cindy McCain) was constantly standing behind her husband's back. Even during the debate, the name "Michelle" was mentioned by Barack at least twice when he was answering the question "What don't you know and how will you learn it?". The future president presented his wife as a source of wisdom and emphasized her authority in many cases. His opponent conversely has not reflected on his wife at all. There were a lot of factors that influenced Obama's victory in this debate, but the factor of his spouse was not without meaning. ${ }^{3}$ The third debate in Hempstead showed that McCain had learned his lesson and that he was the candidate who mentioned his spouse's name at this debate, but in a completely other context than Obama did before.

Taking into account everything mentioned above, Michelle Obama may be qualified as a "front-row place" spouse of the candidate. She was present in all levels of media. While this was not reflected on Instagram or Twitter as they didn't enjoy the same levels of use today, but paper magazines and TV provided a rich source of visibility for her activities. Furthermore, her husband constantly emphasized the importance of her presence and support during campaign. He portrayed Michelle as a positive influence, stating that she was setting an example for him. It could then create the impression that not only for him, but also for Americans that she might be a good example to follow. Michelle

${ }^{3}$ USA Today/Gallup reaction poll finds a random sample of debate watchers saying Barack Obama (56\%) did a better job than John McCain (23\%) in Tuesday's town hall debate (Jones, 2008). 
Obama was not ignored during important events, and often attended meetings with voters either alone and or with her husband - such as at those prior mentioned debates.

Concerning the reaction after Melania Trump's speech during the Republican National Convention, it was strongly different. Before the convention, she was interviewed, expressing herself as a beloved wife whose role is to take care of her son and not to participate in her husband's campaign (Brzezinski, 2016). Accordingly, she vanished for a while after her speech in July (Jordan, McCrummen, 2016). This disappearance was so noticeable that hashtags like \#whereisMelania or \#FreeMelania were commonly use on Twitter or Instagram - the media of modern era elections, mostly as a weapon deployed by Democrats. She gained headlines such as "The Silent Partner" or "Refuses to Act Like First Lady" later on (Wright, 2017). The strategy of Trump's campaign was then to cover his spouse's absence by his daughter Ivanka and her husband Jared Kushner. Ivanka was the one who appeared next to her father at almost all the important events as the female factor and as the one who could attract female votes. In the period between Republican National Convention and the election day on the $8^{\text {th }}$ of November 2016 comparing to Michelle Obama - during the same period of time in 2008 - Melania Trump has not appeared on any of the domestic magazine covers or given any interviews. The only one she appeared on was the caricatural cover of "The Week" on July 2016, right after her speech. She was then sometimes placed on the covers of foreign magazines such as Russian "Tatler Magazine" (October 2016) or French "Vanity Fair” (August 2016). What can be considered surprising is that candidates' spouses normally have made more public speeches than vice presidents during the past administrations of Clinton and Bush, and almost 30\% Michelle Obama's public speeches were delivered during campaign settings. Trump's wife represented a divergence from this level of activity throughout his campaign. After a seven-week absence in the mentioned period, Melania Trump eventually appeared at a campaign event at a national security forum, where she was sitting in the audience. The night before the September 11 anniversary, Melania eventually explained that she has been spending time with her family. Even during her absence, she became an object of controversy rather than a secret weapon for collecting votes. Media began to question her legal status when she arrived to the USA just after the publication of nude photos in early August by the New York Post, which triggered another difficult situation for Trump's campaign. (Schreckinger, Debenedetti, 2016). Those pictures were supposedly taken in 1995 on US territory (Caldwell, Pearson, 2016). What is important, Melania Trump always claimed that she arrived in the country in 1996, so questions were raised about her immigration status at the time - the case became commonly known as "wifegate" (Elder, Frederick, Burrell, 2018, pp. 117-120). The "wifegate" situation ended up with YouGov querying Americans "whether it is appropriate or inappropriate to publish nude pictures of Melania Trump as a way to attack Donald Trump?" and 77\% polled thought this was inappropriate - without partisanship on this issue - as results were similar among Republicans and Democrats. Eventually Melania herself decided to respond those allegations of illegal immigration status by posting a letter from her immigration attorney on her Twitter account that assured "with 100 percent certainty, she correctly went through the legal process when arriving in the USA" (Trump, 2016).

Until $8^{\text {th }}$ of November 2016, Donald Trump participated in three presidential debates, accompanied by his spouse and his daughter Ivanka. The first presidential debate for 
the 2016 election took place on September 26 at Hofstra University in Hempstead and set the record as the most-watched debate in American history, with 84 million viewers, while the second presidential debate took place on October 9 in St. Louis and the third one took place on October 19 in Las Vegas (Peters, Haberman, 2016). On September 26 during the first debate, it was commonly noticed that the appearance of Melania Trump made a big impression, particularly while she was shaking hands with the former President Bill Clinton as part of the pre-debate protocol. Although during this debate she remained unnoticeable in Donald Trump's answers - he did not mention Melania's name even once. The only name mentioned during Hofstra University debate was the one of "Bill Clinton" in the context of NAFTA agreement, which was used as an attack on Hillary Clinton. Similarly, in the second debate, the name of Melania remained unmentioned, and again the only name of spouse used in political contexts - was the name of "Bill Clinton" (Rosenthal, 2016). Right before the last presidential candidates debate in Las Vegas, Melania Trump decided to break her silence in an interview with Anderson Cooper from CNN. What was noticeable was that she was trying to defend her husband after the video revelation of Donald Trump admitting to having sexually assaulting women. She used similar arguments to Trump's opponent while defending her spouse (Rappeport, 2016). Melania went further with arguments that Donald Trump could not have harassed or assaulted a woman he deemed unattractive, even though such behavior is not about desire but power, control and hostility - as she agreed with Anderson Cooper (Bradner, 2016).

It raised a lot of tension between the presidential candidates before the last debate. As Trump's aides developed an elaborate plan to bring three women who accused Mr. Clinton of sexual assault and rape into the family seating area, and to force Mr. Clinton to shake their hands as he crossed the room. This was another moment of the campaign when all eyes were focused on candidates' spouses. At the debate in St. Louis, departing from tradition, Mrs. Clinton and Mr. Trump did not shake hands at the start, though they did at the conclusion of the 90 minutes as well as during the Las Vegas debate. These efforts of Melania to protect her husband during the CNN interview were overshadowed by her appearance on the debate in Las Vegas. Given that candidates' spouses do not speak at debates, but are often featured in cutaway shots and during the final exit, it is what they wear that speaks for them. Certainly, Trump's family - including Melania - choices were impactful enough that they did not escape viewers (Uffalussy, 2016). Melania Trump was not just wearing black, she was again wearing a pussycat bow blouse, a subject of much talk after the previous debate because of her husband's vulgar taped comments - which could not be missed by Trump's campaigning staff. Why she chose that look - whether to suggest that there was no implicit meaning of her husband's hand in the choice, as so many commentators seemed to hope last time or the opposite - was unclear. At the same time, Mrs. Clinton's white suit was unmissable during this debate. Eventually, Melania Trump's and her family outfit caused another antagonism - no matter what your politics are the comparison is: black versus white (Friedman, 2016). Where "black" was the color associated with Trump's voters and "white" was associated with Clinton's electorate.

Right after those debates and ahead of election day, Melania Trump decided to speak in front of voters in Pennsylvania. She spoke by herself, and "portrayed her husband as 
a devoted family man with deep love and respect for all Americans with a speech intended to help soften his public image with women" (Gambino, 2016). As Trump's wife promised that electing Trump would put the country on course to economic prosperity, and that by his side, she would help promote "respect and kindness" in all facets of American life (Gambino, 2016). The place of Melania speech - the state of Pennsylvania was a key battleground - was significant as the speech was directed to suburban women who remain wary of the Republican candidate. Chester County, where she spoke was unique as it is the only "collar county" around Philadelphia not to start supporting Democrats in 1992 (Encyclopedia of Chicago, 2005). President Obama did win it in 2008, before losing it in 2012, and in 2016 voter registration trends had shown the Democrats gaining ground there, so Melania speech contributed to Clinton's lead in Pennsylvania decreasing slightly as the race tightened in the final days of the campaign.

Taking into consideration the events mentioned, Melania Trump may be qualified as a "behind-the-scene" type of candidate's spouse. She was not a common participant during campaigning events. Her appearance in traditional media was nearly invisible, particularly in the American media. Her presence in popular social media as for example Twitter was based particularly on explaining other scandals concerning herself. At almost all political events, she was not treated by Trump as an equal partner - but rather like a required factor for winning an election. She did not have a lot of time for speeches or presenting herself to the wider public. If she did, it was rather with the aim of presenting her husband in a good light, without focusing on herself at all. While she was trying to convince electorate to believe in her husband and his proper behavior in ambiguous situations.

\section{Evaluation of candidates' spouses}

The media often refers to spouses as the presidential candidate's secret weapon, and rarely the candidate himself is more popular. Since 1988 there were only three exceptions to this rule - the first one were the Clintons in 1996 when Bill Clinton's favorable average was a little higher than Hillary Clinton's, than the second took place with John Kerry and Teresa Heinz in 2004, and interestingly last were the Obamas in 2008 (see Table 2 below) (Dugan, 2018). All those mentioned efforts above, not only those of Michelle Obama or Melania Trump, but also others lead us to the general conclusion that each and every speech, public appearance, interview, cover story or even tweeting has a lot of influence on candidates' spouse's favorability among American society. This favorability is eventually a clear measure for voting preferences of Americans, providing a clear purpose for candidates' spouses - winning the office for their partners.

According to the mentioned surveys in 2008 Michelle Obama was one of the most popular candidates' spouses since research began, while measuring favorability in relation to Melania Trump showed that she and her opposite Bill Clinton in 2016 were the most unpopular candidate spouses since 1988 (Burrell, Laurel, Frederick, 2011). These factors of favorability simply reflect the number of votes for presidential candidates. It is worth to notice that Barack Obama was very popular among Americans - in some period of time, as his rating of favorability was higher than his wife and during the elections, 


\section{Table 2.}

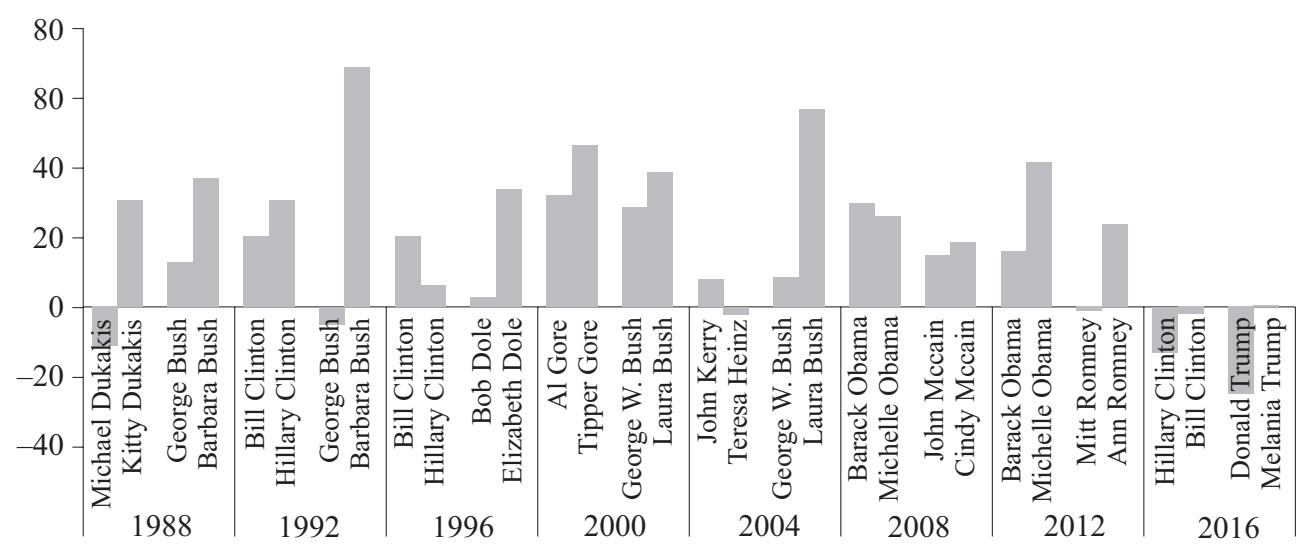

Source: Elder, Frederick, 2018, p. 44.

he was supported by $56 \%$ of female votes. In general, he gained more female than male votes (How Groups..., 2008). This effect should not be surprising as his spouse was an important ally in the presidential race. Her "front - row" position may have convinced a lot of women to vote for Barack Obama, as the female part of the electorate may identify with her as a strong woman who is receiving a lot of respect from husband.

The situation for Donald Trump appears to be different. The favorability ratings for both he and his wife were relatively low. Unprecedented low favorability ratings resulted in Trump only gaining 47\% of female votes during 2016 elections, compared to $53 \%$ of male votes in this election (Doherty, 2018). This and of course, the whole activity of both wives - Michelle and Melania - may have a huge impact on the voting results, but it is worth noticing that Barack Obama received $9 \%$ more female votes than Donald Trump. That simply means that the activities and appearance of Michelle Obama resulted in more votes from women than Melania Trump was able to obtain for Donald Trump. The question concerning Melania is that her activity was not as visible as Michelle on one hand, but on the other hand, Donald Trump's rival was the first female candidate - Hillary Clinton. That gender factor had a clearer impact on female votes toward Trump.

Barack Obama's wife had a high rating of favorability during the whole campaign trail. She remained at an average mark at the level of $44 \%$ favorable and $21 \%$ unfavorable among a group of representative adults. However, after serving for four years in White House, she used all the advantages that come with the office to enhance her personal standing in the eyes of the public even further - recently she received a rating of around 64\% favorability (McCarthy, 2016). Before becoming the First Lady, she put a lot of effort to gain such a favorability rating during the entire 2008 campaign. At the beginning - before the 2008 primaries and during the rest of campaign - Michelle Obama remained one of the most active candidates for the First Lady in terms of campaigning for her husband. She started with a 48\% favorability rating on June 2008 and she ended in October with a rating of around 67\% (Henderson, 2009). This result at the beginning of the campaign was not taken seriously as Cindy McCain - the spouse of Obama's rival had a similar result in June 2008. The situation changed after the National 
Democratic Convention where Michelle gave "her speech." It was a turning point not only in her image but also in her favorability ratings that kept rising up until Election Day (Williams, 2009, p. 833-850). Those ratings grew simultaneously after each cover or interview during the campaigning period. What is more important, at that time she kept quite low ratings of unfavorable opinion, which hovered around $21 \%$ during the whole campaign (Political Figures, 2019). Despite that high ratings Michelle Obama did not break the record of positive opinions among Americans as a first lady during the 2008 presidential campaign (Burns, 2020, pp. 145-150). Her ratings were dwarfed by Laura Bush (Republican candidate spouse) whose average rating was around $73 \%$ of favorability in 2001 (Jones, 2012). Even Obama's wife's efforts in the White House for eight years did not change these standards. Nevertheless, Michelle Obama or Laura Bush were not unbeatable - their top places was taken by former president's wife Barbara Bush whose $77 \%$ favorability rating is the highest of all since 1988 (Barbara Bush beats Michelle..., 2014).

Favorability ratings regarding Melania Trump was one of the lowest in history of the research carried out on this topic. She was one of the least popular potential first ladies since 1988. Her unfavorable ratings do have at least one comparison - Hillary Clinton in August 1996. At that time, before the re-nomination of Bill Clinton, Hillary Clinton's image was split at 47\% favorable and 48\% unfavorable. While in July 2016, right before Trump's speech in front of a Republican crowd in Cleveland, American overall opinion found her to be favored by $28 \%$, while $32 \%$ considered her unfavorably (Saad, 2016). The Republican National Convention has slightly changed these ratings among Americans. The future first lady ratings rose to $38 \%$ of favorability among the group of "national adults" (Newport, 2018). However, it was a missed chance for Melania Trump as her unfavorable ratings climbed as well by around 6 points after her speech. Her rating of favorability has not changed since than throughout the whole campaign. As it was mentioned above, she had not done particularly much to change this status of favorability. Donald Trump's aides kept her from the public eye for the rest of the presidential race, apart from a few appearances. Her perception by Americans until the day of election has not changed. She kept the same level of support from the convention up to the end of October 2016 - at the same rate over the campaign with around $38 \%$ of favorability compared to $38 \%$ of unfavorable ratings. Public opinion did not record even small changes in her favorability after her interview for CNN on October or her appearances in foreign magazines (Elder, Frederick, Burrell, 2018, p. 115, table 5.1). Even though Melania Trump eventually had obtained a chance to change Americans' opinion about her, in fact, she only started to change people's opinion once her husband was elected as President. Her ratings raised throughout the last four years in the White House from $38 \%$ to $57 \%$ on May 2018 according to CNN Polls. Nearly 6 in 10 Americans at that time had a positive view of the first lady (We'd like to get your overall..., 2018). It was her highest result in such polls.

While some Americans generally have greater sympathy for candidate spouses than other national political figures, this sympathy is only justified when the future president's spouse operates within the traditional expectations for spouses of candidates. As Michelle Obama allowed American women to identify with her not only by race or political identity but also as a working-mother, an independent woman and as a feminist. She 
emphasized how important those values are for her in nearly each and every speech or interview she did during the 2008 campaign. Obama's wife provided an important form of representation to underrepresented groups who have historically had very little representation, such as women and African-Americans. In return, those groups viewed her very favorably and rewarded her husband with crucial votes (Caroli, 2010, pp. 123-128). It is however important to remember that not all factors come as a result of her campaigning activities. Identification with race for example is an independent factor that may affect her favorability ratings among African Americans. She did not have to earn this status, similarly to Melania Trump who did not have to earn her foreign-born status.

Although the opportunity to use "this foreigner card" in Trump's campaign was missed as Melania Trump struggled to identify with fellow migrants, instead standing by her husband's opinions in that matter. She was also not active on the campaign trail, which helped to create possibilities for negative perceptions among minority voters. Eventually it resulted in convincing just $28 \%$ of Hispanic men and the same number of Hispanic women to vote for Donald Trump. It was apparently easier to convince a group who may identify with Melania Trump completely, such as similar "married women" $48 \%$ of whom voted for Donald Trump, compared to just 30\% of unmarried women (Doherty, 2018). Even her efforts to identify with stay-at-home mothers was a missed chance, as she signaled during the 2016 campaign season that her first goal is to be a mother for her son and with her dedication to motherhood. It did not find any significant acceptance among female voters preferred to support her opponent Bill Clinton - even in light of previous scandals during his presidency (Elder, Frederick, Burrell, 2018, p. 130, table 5.3). Neither was it easy for Melania Trump to gain feminist votes, especially after her interview for $\mathrm{CNN}$ where she was trying to defend her husband against charges of sexual harassment. All those elements of campaigning proved that gender in Melania Trump's case was not a significant factor in favorability ratings, contrary to Michelle Obama. In the case of Michelle Obama, she improved her public image with widespread activities along with her husband during the 2008 campaigning season.

Even as those two strategies of how their wives were portrayed during the campaign by Obama and Trump were different, they gave similar results and eventually helped both candidates win their first presidential races. One of the differences is the aforementioned rates of favorability. The strong participation in the campaign by Michelle Obama made her one of the most likable persons among candidates' spouses while the case of Melania Trump was completely opposite (Zhang, 2017, pp. 33-44). The strategy of Trump to keep his wife in shadow throughout whole campaign did not cost him victory, but certainly made Melania the least likable future first lady since 1988. It should be concluded that the "front - row" position for candidates" spouse may result in gaining more female votes in elections while a "behind-the-scenes" position resulted in lower votes from women. Although it should not be the only factor to take under consideration when trying to win female votes, establishing future first ladies in a strong position during the campaign undoubtedly helps.

Being the future president's spouse is a unique role to play and while Obama's and Trump's wives styles have varied, certain behaviors like involvement in the campaign are important factors. Americans are supportive not only of the First Lady but also of candidates' spouses having an influence on campaign and policy, even though this 
position has rather largely ceremonial features. What legitimate presidential candidate spouses in spotlight is not their political power, but on level of very private act of who are they married to. This division between private and public lives in modern political life has almost vanished in relation to candidates' spouses. In an era of social media and fast developing journalism, these wives may be a secret weapon for candidates, but may also cause or undermine their qualifications for public office. They can sometimes may be an important messenger for presidential candidates as spouses are able to appeal to different and broader audiences than their partners. These are the roles that they should be prepared to play, but as described, research carried out over the last few decades bring different techniques of using it in order to achieve votes in presidential races.

\section{Bibliography}

Bankert A. (2020), Negative and Positive Partisanship in the 2016 U.S. Presidential Elections, "Political Behavior".

Barbara Bush beats Michelle Obama in popularity poll (2014), "Asian News International Retrieved", 5.03.2014.

Borrelli M. A. (2011), The Politics of the President's Wife. College Station, Texas A\&M University Press.

Burns L. M. (2020), Media Relations and the Modern First Lady: From Jacqueline Kennedy to Melania Trump, Lexington Books, Maryland.

Burrell B., Elder L., Frederick B. (2011), From Hillary to Michelle: Public Opinion and the Spouses of Presidential Candidates, "Presidential Studies Quarterly", vol. 41, no. 1.

Bradner E. (2016), Melania Trump: Donald Trump was 'egged on'into 'boy talk', 17.10.2016, Cnnpolitics.com, https://edition.cnn.com/2016/10/17/politics/melania-trump-interview/index.html, 10.12.2019.

Brown N. (2014), Sisters in the Statehouse: Black Women and Legislative Decision, Making, Oxford University Press, New York.

Brzezinski M. (2016), Morning Joe, MSNBC.com, 24.02.2016, https://www.realclearpolitics.com/ video/2016/02/24/mika_brzezinski_interviews_melania_trump_html, 12.12.2019.

Caldwell A. (2016), Melania Trump Modeled in US Prior to Getting Work Visa, "Associated Press", 5.11.2016, https://apnews.com/37dc7aef0ce44077930b7436be7bfd0d. 12.12.2019.

Caroli B. (2010), First Ladies: From Martha Washington to Michelle Obama, Oxford University Press, New York.

Collar Counties (2005), in: Encyclopedia of Chicago, http://www.encyclopedia.chicagohistory.org/ pages/3.html, 12.12.2019.

Doherty C. (2018), For most Trump Voters 'Very Warm' Feelings for Him Endured, people-press.org, 9.08.2018, https://www.people-press.org/2018/08/09/for-most-trump-voters-very-warm-feelings-for-him-endured/, 10.12.2019.

Dugan A. (2018), Hillary Clinton's Favorable Rating Still Low, Gallup.com, 28.08.2018, https://news. gallup.com/poll/243242/snapshot-hillary-clinton-favorable-rating-low.aspx, 10.10.2019.

Gold H. (2014), Bush speechwriter: Obama plagiarized Bush, Politico.com, 29.01.2014, https:// www.politico.com/blogs/media/2014/01/bush-speechwriter-obama-plagiarized-bush-182184, 10.10.2019.

Elder L., Frederick B., Burrell B. (2018), American Presidential Candidate Spouses, Palgrave Macmillan, Cham. 
Friedman V. (2016), In the Final Presidential Debate, the Trumps Go Dark, "The New York Times", 20.10.2016.

Gambino L. (2016), Melania Trump takes on cyberbullying: <Our culture has gotten too mean>, "The Guardian", 3.11.2016.

Haberman M., Barbaro M. (2016), How Melania Trump's Speech Veered Off Course and Caused an Uproar, "The New York Times", 19.07.2016.

Henderson N. (2009), Michelle Obama's poll numbers slid, Politico.com, 11.09.2009, https://www. politico.com/story/2009/11/michelle-obamas-poll-numbers-slide-029347, 2.02.2020.

How Groups Voted in 2008 (2008), Roper Center, https://ropercenter.cornell.edu/how-groups-voted-2008, 9.12.2019.

Ioffe J. (2016), Melania Trump on Her Rise, Her Family Secrets, and Her True Political Views: 'Nobody Will Ever Know', “GQ Magazine”, 27.04.2016.

Jones J. (2008), Obama Rated as Winner of Second Presidential Debate, Gallup.com, 9.10.2008, https://news.gallup.com/poll/111058/obama-rated-winner-second-presidential-debate.aspx, 12.12.2019.

Jones (2012), Michelle Obama Remains Popular in U.S, Gallup.com, 30.05.2012, https://news.gallup. com/poll/154952/michelle-obama-remains-popular.aspx, 08.12.2019.

Jordan M., McCrummen S. (2016), After Convention Stumble Melania Trump has Largely Stumbled From Campaign Trail, "Washington Post", 8.08.2016.

Kaufman J., Langley M. (2008), With Monday Speech, Michelle Obama Seeks Reintroduction, "The Wall Street Journal", 26.08.2008.

Kelley A. (2016), Section Of Melania Trump's Monday Speech Mirrors Michelle Obama's In 2008, https://www.npr.org/2016/07/19/486560186/section-of-melania-trumps-monday-speechclosely-imitates-michelle-obama-in-2008.

Lizza R. (2016), Three Problems with the Melania Trump Plagiarism Admission, "The New Yorker", 20.07.2016, https://www.newyorker.com/news/news-desk/three-problems-with-the-melaniatrump-plagiarism-admission, 10.10.2019.

MacManus S., Quecan A. (2008), Spouses as Campaign Surrogates: Strategic Appearances by Presidential and Vice Presidential Candidates' Wives in the 2004 Election, "Political Science \& Politics", vol. 42, no. 2, pp. 337-348.

MacAskill E. (2008), Michelle Obama speaks of Barack's qualities as a man, husband and father, "The Guardian", 26.08.2008, https://www.theguardian.com/world/2008/aug/26/michelleobama. democrats2008, 5.02.2020.

Mandziuk R. (2017), Whither the Good Wife? 2016 Presidential Candidate Spouses in the Gendered Spaces of Contemporary Politics, "Quarterly Journal of Speech", vol. 103, no. 1-2, pp. 136-159.

Mast N., Hargis C. (2016), Here's Who's Defending Melania Trump's Plagiarized Speech And Who's Calling It Out, 19.07.2016, https://www.mediamatters.org/laura-ingraham/heres-whos-defending-melania-trumps-plagiarized-speech-and-whos-calling-it-out, 2.03.2020.

Michelle Obama shows her husband's personal side (2008), thecurrent.org, 25.08.2008, https://www. thecurrent.org/feature/2008/08/25/michelle_obama_speech, 28.12.2019.

McCarthy, Michelle Obama More Popular Than Bill Clinton, Melania Trump, Gallup.com, 12.08.2016, https://news.gallup.com/poll/194567/michelle-obama-popular-bill-clinton-melania-trump. aspx, 5.12.2019.

Newport F. (ed.) (2018), The Gallup Poll: Public Opinion 2016, Rowman \& Littlefield Publishers, Maryland.

Obama M. (2008), Michelle Obama's Convention Speech, 25.08,2008, https://www.npr.org/templates/ story/story.php?storyId=93963863\&t=1585392509836, 3.12.2019. 
Obama M. (2018), Becoming, Crown Publishing Group, New York.

Oinounou M., Kapp B. (2015), Michelle Obama Takes Heat for Saying She's 'Proud of My Country'for the First Time, foxnews.com, 19.02.2008, https://www.foxnews.com/story/michelle-obamatakes-heat-for-saying-shes-proud-of-my-country-for-the-first-time, 7.02.2020.

Peters J. W., Haberman M. (2016), At previous debates, Melania Trump and Bill Clinton shook hands. Not Anymore, "New York Times", 8.10.2016.

Political Figures: Michelle Obama (2019), Polling Report, https://www.pollingreport.com/o.htm, 7.01.2020.

Rappeport A. (2016), Melania Trump, Solo in Pennsylvania, Tries to Smooth Husband's Rough Edges, "The New York Times", 3.11.2016.

Rosenthal A. (2016), Melania Trump Mimics Hillary Clinton to Defend Donald Trump, "The New York Times", 19.10.2016.

Saad L. (2016), Melania Trump's Image Less Positive than Other Spouses, Gallup.com, 18.07.2016, https://news.gallup.com/opinion/polling-matters/193793/melania-trump-image-problem-democrats-independents.aspx, 5.01.2020.

Scharrer E., Bissell K. (2000), Overcoming Traditional Boundaries: The Role of Political Activity in Media Coverage of First Ladies, "Women \& Politics", vol. 21, no. 1.

Schreckinger B., Debenedetti G. (2016), Gaps in Melania Trump's Immigration Story Raise Questions, Politico.com, 4.08.2016, https://www.politico.com/story/2016/08/melania-trump-immigrationdonald-226648, 15.02.2020.

Smith D. (2016), Melania Trump's Republican convention speech: so good it was recited twice, 19.07.2016, https://www.theguardian.com/us-news/2016/jul/19/melania-trump-speech-republican-national-convention, 5.02.2020.

Trump M. (2016), Tweet published 14.09.2016, https://twitter.com/MELANIATRUMP/status/ $776050512772886529 /$ photo/2.

Uffalussy J. G. (2016), Melania and Ivanka Trump Wear Symbolic Color to Third Debate, Says Social Media, YahooNews.com, 20.10.2016, https:/www.yahoo.com/lifestyle/melania-and-ivankaare-wearing-a-symbolic-color-to-the-third-debate-say-social-media-020522709, 12.01.2020.

We'd like to get your overall opinion of some people in the news (2018), CNN/SSRS Poll, http://cdn. cnn.com/cnn/2018/images/05/07/rel5a.-.melania.trump.pdf, 14.01.2020.

Williams V. (2009), The First (Black) Lady, "Denver University Law Review”, vol. 86, pp. 833-850.

Wright L. (2016), On Behalf of the President: Presidential Spouses and White House Communications Strategy Today, Praeger, Westport.

Wright L. (2017), Melania Trump Refuses to Act Like a First Lady. Good for Her, "Washington Post", 19.01.2017.

Zhang L. (2017), The Soft Power of a First Lady - Constructing Identities for First Ladies in the Chinese and American Media, "Discourse, Context \& Media", vol. 20, pp. 33-44.

\section{Udział współmałżonek kandydatów w prowadzeniu kampanii prezydenckich w 2008 roku i 2016 roku: analiza porównawcza}

\section{Streszczenie}

Każdy kandydat na prezydenta w Stanach Zjednoczonych powinien pokazywać się podczas kampanii wyborczej z żoną u boku. Zaangażowanie pierwszych dam takich jak Michelle Obama czy Melania Trump w kampanie prezydenckie ich mężów daje badaczom współczesny obraz przyszłej pierwszej damy i możliwość badania bardziej lub mniej pożądanych zachowań podczas kampanii wyborczych. 
Celem niniejszego artykułu będzie porównanie obu wymienionych wyżej żon kandydatów na urząd prezydenta w Stanach Zjednoczonych. Porównanie ich działalności i zachowań podczas pierwszych prezydenckich kampanii ich mężów tj. w 2008 roku i 2016 roku unaoczni różnice w traktowaniu żony kandydata podczas kampanii prezydenckiej w obozie Demokratów i Republikanów. Celem badania jest zaobserwowanie pewnych prawidłowości w sposobie traktowania żon kandydatów na prezydenta podczas kampanii wyborczych, jak również odpowiedź na pytanie czy istnieje bardziej lub mniej pożądane zachowanie „pierwszych żon”, które to przysparza kandydatowi jak najwięcej wyborczych głosów. Artykuł oparty jest na jakościowej analizie istniejących danych zgromadzonych podczas wyborów w 2008 roku oraz w 2016 roku, jak również na krytycznej analizie istniejącej literatury przedmiotu. W celu rozwinięcia powyższych metod autor dokona porównania politycznych pozycji przyszłych pierwszych dam - Michelle Obamy i Melanii Trump podczas wspomnianego okresu kampanii prezydenckich, także poprzez zebranie statystyk obrazujących ich obecność w mediach oraz podczas publicznych wystąpień.

Słowa kluczowe: kampania prezydencka, żona prezydenta, Partia Demokratyczna, Partia Republikańska, żona kandydata 
